\title{
TINGGINYA ANGKA CERAI GUGAT DI PENGADILAN AGAMA PEKANBARU DAN RELEVANSINYA DENGAN KONSEP KESETARAAN GENDER
}

\author{
Johar Arifin \\ UIN Suska Riau, Indonesia \\ johar.arifin@uin-suska.ac.id \\ Ahmad Mas'ari \\ UIN Suska Riau, Indonesia \\ ahmad.mas’ari@,uin-suska.ac.id
}

\begin{abstract}
This study aims to bring the question, is there any relevance of gender equality concept with high divorce number in PA Pekanbaru? The type of research used is research that is poured in the form of qualitative by using gender approach in Islam. Primary data sources in this study were interviews with the competent parties by purposive sampling. The conclusion of this study is that the paradigm of gender equality is a contributing factor to the height of divorce in PA Pekanbaru although not as the main factor. Gender equality here can be positive when it is associated with legal awareness for women as a solution to the chaos of the household they are experiencing. Conversely, gender equality connotes negatively if the excess possessed by the woman is used as an excuse to sue her husband's divorce. Although informants are less knowledgeable about conceptions of gender, in general the views of informants have a conceptual appeal to the view of liberal feminism, in which women should have equal rights with men.
\end{abstract}

Keyword: Gender, Patriarchy, Divorce, Sues, Livelihood.

\section{ABSTRAK}

Penelitian ini bertujuan untuk menjawa pertanyaan, apakah ada relevansi konsep kesetaraan gender dengan tingginya angka cerai gugat di PA Pekanbaru? Jenis penelitian yang digunakan adalah penelitian yang dituangkan dalam bentuk kualitatif dengan menggunakan pendekatan gender dalam Islam. Sumber data primer dalam penelitian ini adalah wawancara dengan pibak-pibak yang berkompeten secara purposive sampling. Kesimpulan penelitian ini adalah babwa paradigma kesetaraan gender termasuk faktor penyumbang tingginya cerai gugat di PA Pekanbaru, walaupun bukan sebagai faktor utama. Kesetaraan gender di sini bisa bermakna positif apabila dikaitkan dengan kesadaran bukum bagi perempuan sebagai solusi atas kekisruban rumah tangga yang dialaminya. Sebaliknya, kesetaraan gender berkonotasi negatif apabila kelebihan yang dimiliki oleh perempuan tersebut dijadikean alasan untuk menggugat cerai suaminya. Walaupun para informan tidak terlalu paham terbadap konsepsi tentang gender, namun secara umum pandangan para informan memiliki kesesuaian konseptual dengan pandangan feminisme liberal, di mana perempuan harus mempunyai bak. yang sama dengan lakilaki.

Keyword: Gender, Patriarkhi, Cerai, Gugat, Nafkah. 


\section{A. PENDAHULUAN}

Maraknya berbagai pemberitaan di media masa akhir-akhir ini tentang perceraian beberapa figur publik sepertinya merupakan gambaran dari kondisi gunung es yang terdapat pada masyarakat Indonesia, terutama para pasangan suami-istri. Banyaknya tokoh atau figur publik yang disorot seakan menunjukkan peningkatan jumlah kasus perceraian sekarang ini. Sebagai contoh saja, menurut data dari bagian kepaniteraan Pengadilan Agama Pekanbaru, cerai gugat yang diajukan istri kepada suami meningkat drastis selama 2013. Dari 1.426 kasus perceraian, sebanyak 1.016 di antaranya diajukan kaum istri (cerai gugat). Sisanya 410 kasus, diajukan suami (cerai talak). Jika dikalkulasikan, cerai gugat mencapai angka 70 persen dibanding cerai talak. Dari kasus yang terjadi di Pengadilan Agama Pekanbaru, diketahui banyak gugat cerai diajukan wanita karir.

Tingginya angka cerai gugat yang diajukan oleh pihak istri memberikan gambaran bahwa sekarang ini pengetahuan istri terhadap kesadaran hukum semakin tinggi. Istri tidak hanya mengekor keinginan suami di mana tugas istri tidak jauh dari dapur, sumur dan kasur. Kemajuan pengetahuan yang dimiliki oleh kaum istri menjadikan keberadaan istri di rumah tidak boleh lagi dipandang istri sebagai pelengkap rumah tangga yang keberadaanya hanya mengatur rumah dan menunggu uluran tangan dari sang suami.

Menurut data angka perceraian di Pengadilan Agama Pekanbaru di atas, memang bisa membuat siapa saja tidak percaya. Betapa tidak, fakta hancurnya mahligai pernikahan di Kota Pekanbaru ini sedang jadi trend yang terus meningkat setiap tahunnya. Data angka perceraian di Pengadilan Agama Pekanbaru selalu didominasi gugat cerai dari pada cerai talak, yang artinya lebih banyak perceraian karena permintaan kaum hawa dari pada permintaan kaum Adam. Posisi perempuan kian dipersalahkan ketika ada pendapat yang mengatakan bahwa faktor utama penyebab perceraian adalah kekeliruan penerapan gender, di mana perempuan lebih dominan mengambil alih fungsi peran laki-laki. Kesetaraan gender yang sekarang ini diperjuangkan oleh kaum perempuan merupakan konsepsi yang sangat mengharapkan kesetaraan hubungan yang serasi dan harmonis antara kaum perempuan dengan kaum pria, di mana ide utama yang diangkat adalah wanita harus disetarakan dengan pria dalam segala bidang. Para pejuang gender menghendaki agar perempuan diberikan hak yang sama dengan laki-laki (gender equality). Perempuan harus dibebaskan dari beban-beban yang menghambat kemandirian, sekalipun harus mereduksi nilai-nilai budaya dan agama. 
Dalam hal ini tentu saja sebelum gender itu diterima sebagai suatu konsep yang memasyarakat, terlebih dahulu haruslah dipahami permasalahan kesetaraan hak perempuan untuk memperoleh kesempatan dalam memperoleh pendidikan maupun dalam lingkungan dunia kerja. Ada sebagian masyarakat yang khawatir dengan adanya persamaan gender ini, dan ada juga yang berpendapat bahwa kesetaraan gender dapat menjadi penegasan keseriusan bersama menjadikan kesetaraan gender bukan hanya sebagai wacana semata, namun juga aplikasi serta menyokong kebijakan-kebijakan yan sudah ada mengenai hak serta perlindungan terutama bagi perempuan.

Banyaknya keuntungan yang didapat dari kesamaan gender bukan berarti tanpa kekurangan. Dalam kehidupan rumah tangga apabila seorang istri bekerja- apalagi kalau sama-sama sering lembur- membuat perhatian terhadap pasanganya dan anaknya menjadi terbengkalai. Padahal dalam sebuah rumah tangga pembinaan hubungan antara suami istri sangatlah penting. Sering seorang suami atau istri baru menyadari belakangan ketika hubungan antara sang suami atau istri sudah mulai kurang harmonis. Kalau hal tersebut dibiarkan berlarut-larut, maka akan mengakibatkan rumah tangga mereka menjadi retak bahkan banyak juga yang berujung ke Pengadilan Agama.

Hal inilah yang akan dibahas dalam tulisan ini. Secara ringkas pembahasan tulisan ini adalah perdebatan peran seorang perempuan dalam rumah tangga antara konsep kesetaraan gender serta korelasi dengan tingginya cerai gugat di Pengadilan Agama Kota Pekanbaru.

\section{B. TINJAUAN PUSTAKA}

\section{Cerai Gugat Perspektif Hukum Positif dan Islam}

Cerai gugat atau yang disebut dengan khulu', dengan mengutip pendapat secara syariah adalah kata yang menunjukkan atas putusnya hubungan perkawinan antara suami istri dengan tebusan [dari istri]yang memenuhi syarat-syarat tertentu. Setiap kata yang menunjukkan pada talak, baik sharih atau kinayah, maka sah khulu-nya dan terjadi talak ba'in (Al-Jaziri). Ibnu Hajar aAl-Asqalani dalam Fathaul-Bari mendefinisikan bahwa khulu' adalah isteri yang menebus dirinya sendiri dengan harta yang diberikan kepada suami. (Al-Asqalani: 1409 H/ 1989 M). Adapun pengertian dari cerai gugat menurut hukum di Indonesia yaitu isteri menggugat suaminya untuk bercerai melalui pengadilan, yang kemudian pihak pengadilan mengabulkan gugatan dimaksud sehingga putus hubungan penggugat (isteri) dengan tergugat. Sedangkan 
cerai gugat menurut Pasal 73 Undang-undang Nomor 7 Tahun 1989 tentang Peradilan Agama dalam Pasal 73 adalah gugatan perceraian yang diajukan oleh isteri atau kuasanya kepada Pengadilan yang daerah hukumnya meliputi tempat keadilan penggugat, kecuali apabila penggugat dengan sengaja meninggalkan tempat kediaman bersama tanpa izin tergugat. Jadi, cerai gugat (Dengan demikian, khulu') merupakan bentuk institusi talak yang miliki oleh seorang isteri untuk memutuskan tali perkawinan dengan suaminya dengan memberikan tebusan yang sesuai berdasarkan kesepakatan.

Al-Syirazi dalam al-Muhadzdzab menyatakan bahwa khulu' itu boleh secara mutlak walaupun tanpa sebab asalkan kedua suami isteri sama-sama rela. Apalagi kalau karena ada sebab, baik sebab yang manusiawi seperti isteri sudah tidak lagi mencintai suami, atau sebab yang syar'i seperti suami tidak shalat atau tidak memberi nafkah. (Al-Syirazi, 1407 H/1987 M).Kebolehan khulu'dalam Islam ini. Dasar hukum dari masalah gugat cerai khulu' dalam Islam adalah berdasarkan QS. Al-Baqarah ayat 229:

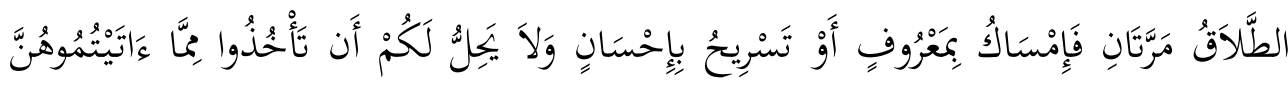

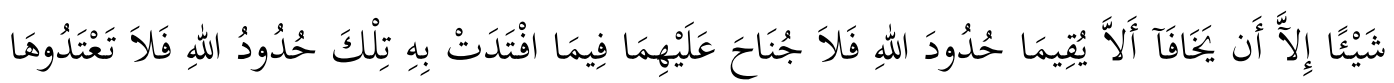

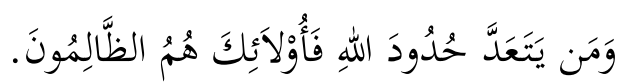

Artinya:

"....jika kamu khawatir bahwa keduanya (suami-isteri) tidak dapat menjalankan bukum-bukum Allah, maka tidak ada dosa atas keduanya tentang bayaran yang diberikan oleh isteri utuk menebus dirinya. Itulah bukum-bukum Allah, maka janganlah kamu melanggarnya. Barangsiapa yang melanggar hukum-hukum Allah, mereka itulah orang-orang yang zalim." (QS. Al-Baqarah [2]: 229).

Selain itu juga berdasarkan hadis Nabi:

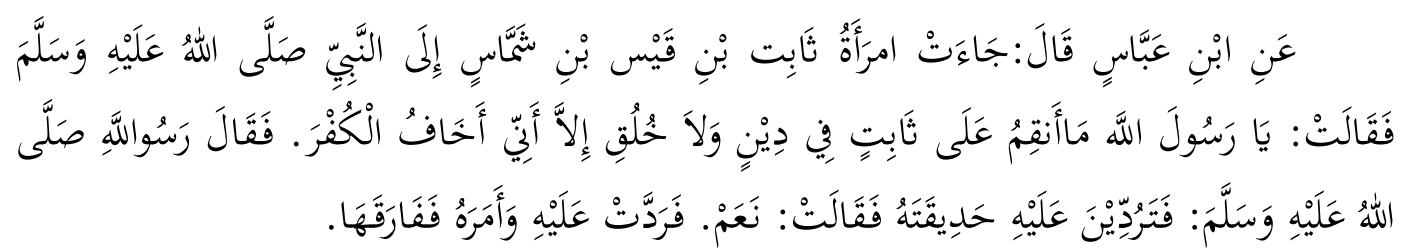

Artinya:

Isteri Tsabit bin Qais bin Syammas mendatangi Nabi Saw seraya berkata: "Wahai Rasulullah, aku tidak membenci Tsabit dalam agama dan akblaknya. Aku banya takut kufur." Maka Rasulullah Saw bersabda: "Mankah kamu mengembalikan kebunnya kepadanya?" Ia menjawab, "Ya." Maka ia mengembalikan kepadanya dan Rasulullab Saw memerintabkan untuk menceraikannya, dan Tsabit pun menceraikannya."(HR. Bukhari) sebuah hadits sabih yang mengisabkan tentang istri Tsabit bin Qais bin Syammas bernama Jamilab binti Ubay bin Salil 
yang datang pada Rasulullah dan meminta cerai karena tidak mencintai suaminya. Rasulullah lalu menceraikan dia dengan suaminya setelah sang istri mengembalikan mahar.

Hukum asal dari khulu' adalah boleh menurut ijmak ulama. Baik tebusannya berupa seluruh mahar atau sebagian mahar atau harta lain yang lebih sedikit atau lebih banyak. Khulu' sah dalam keadaan konflik atau damai (Muzhar (ed), 2001). As-Syairazi dalam Al-Muhadzab menyatakan bahwa khulu' itu boleh secara mutlak walaupun tanpa sebab asalkan kedua suami istri sama-sama rela. Apalagi kalau karena ada sebab, baik sebab yang manusiawi seperti istri sudah tidak lagi mencintai suami; atau sebab yang syar'i seperti suami tidak shalat atau tidak memberi nafkah (Muzhar (ed), 2001).

Pada dasarnya, seorang wanita (isteri) haram meminta (menuntut) cerai terhadap suaminya, kecuali adanya sebab yang dibenarkan,; seperti perlakuan suami yang buruk terhadap dirinya, tidak mencukupkan nafkahnya, suka memukul dan menganiaya, dan semisalnya,- atau tidak ada rasa suka dalam dirinya terhadap suaminya sehingga membuatkan takut akan menelantarkan hak-hak suami. Meminta cerai tanpa ada alasan yang dibenarkan syariat termasuk dosa besar yang wajib dijauhi dan ditinggalkan istri muslimah.

Hal ini berdasarkan hadis Nabi:

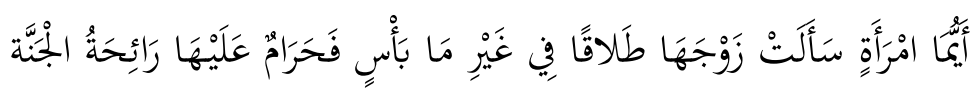

Artinya:

Siapa saja wanita yang meminta (menuntut) cerai kepada suaminya tanpa alasan yang dibenarkan, maka diharamkan bau surga atas wanita tersebut." (HR. Abu Dawud, aAlTirmidəi, dan Ibnu Majah).

Syaikh Muhammad Abdurrahman bin Abdurrahim al-Mubarakfuri, penulis Tuhfahal-Ahwadzi, menjelaskan tentang makna "Diharamkannya bau surga baginya" adalah: "Dia dilarang menciumnya, atau itu terjadi berkaitan pada satu waktu dan tidak pada selainnya. Maksudnya: ia tidak mendapati bau surga di saat orang-orang baik suka berbuat baik (muhsinun) pertama kali menciumnya,atau ia tidak mendapati bau surga sama sekali sebagai ancaman yang serius." (Al-Mubarakfuri, 1407 H/1987 M). Sebagian ulama lain menjelaskan maknanya: diharamkan baginya mencium bau surga walaupun ia memasuki surga tersebut.

Ancaman di atas akan menimpa wanita yang menggugat cerai suami jika tanpa disertai alasan yang dibenarkan. Yaitu alasan yang benar-benar mengharuskannya 
bercerai. Contohnya: perlakuan suami yang buruk -tidak mencukupkan nafkahnya, suka memukul dan menganiaya, dan semisalnya-, suami tidak mau menjalaskan perintah agama \& beraklak buruk, ia membencinya (tidak ada rasa suka/cinta kepada suaminya) sehingga ia tidak bisa hidup bersamanya, terjadi penyimpangan seksual, tidak bisa memenuhi kebutuhan batin, dan semisalnya.

Syaikh Ibmu Jibrin menjelaskan beberapa perkara yang membolehkan seorang wanita mengajukan Khulu':

Pertama, Apabila seorang wanita membenci karakter akhlak suaminya seperti kasar, temperamen, mudah tersinggung, sering marah-marah, terlalu saklek, kurang bisa menerima kekurangan maka ia boleh mengajukan khulu'. Kedua, apabila tidak suka dengan tampangnya seperti memiliki cacat, buruk rupa, kurang pada panca inderanya, maka ia dibolehkan meminta kbulu'. Ketiga, apabila ada cacat dalam agamanya seperti suka meninggalkan shalat, meremehkan shalat Jama'ah, tidak puasa Ramadhan tanpa udzur syar'i, atau melakukan perbuatan haram seperti zina, mabukmabukan, suka nongkrong, maka dibolehkan baginya menuntut khulu'. Keempat, jika suami tidak memberikan haknya seperti nafkah, pakaian, dan kebutuhan pokoknya padahal ia mampu memberikannya; maka istri tersebut boleh mengajukan khulu'. Kelima, apabila suami tidak bisa menunaikan kewajiban nafkah batin karena memiliki penyakit seksual atau tidak adil dalam pembagian jatah giliran. Maka ia boleh mengajukan Kbulu'

Ringkasnya, bahwa istri berkewajiban mentaati suaminya dan memberikan pelayakan yang baik kepadanya. Tidak boleh meminta pisah darinya tanpa ada alasan yang dibenarkan syariat dan tanpa ada bahaya yang bisa mengancamnya. Jika karena sang istri punya Pria Idaman Lain (PIL) lalu ia menggugat cerai suaminya maka ia telah melakukan dosa besar dan diancam dengan kehinaan di akhirat; tidak akan mencium bau surga.

\section{Kesetaraan Gender dan Cerai Gugat}

Gender secara terminologis, menurut Giddens, konsep gender menyangkut tentang "Psypcological, social and cultural differences between males and females", yaitu perbedaan psikologis, sosialsocial, dan budaya antara laki-laki dan perempuan. (Giddens, 1997). Macionis mendefinisikan gender sebagai "The significance a society attaches to biological cathegories of female and male", yaitu arti penting yang diberikan masyarakat pada kategori biologis laki-laki dan perempuan. (Macionis, 2006). 
Dari definisi di atas dapat dipahami bahwa gender adalah suatu sifat yang dijadikan dasar untuk mengidentifikasi perbedaan antara laki-laki dan perempuan dilihat dari segi kondisi sosial dan budaya, nilai dan perilaku, mentalitas, dan emosi, serta faktor-faktor nonbiologis lainnya. Gender berbeda dengan sex, meskipun secara etimologis artinya sama sama dengan sex, yaitu jenis kelamin. Secara umum sex digunakan untuk mengidentifikasi perbedaan laki-laki dan perempuan dari segi anatomi biologis, sedang gender lebih banyak berkonsentrasi kepada aspek sosial, budaya, dan aspek-aspek non biologis lainnya. Kalau studi sex lebih menekankan kepada perkembangan aspek biologis dan komposisi kimia dalam tubuh seorang lakilaki dan seorang perempuan, studi gender lebih menekankan kepada perkembangan aspek maskulinitas dan femininitas seseorang.

Dari beberapa definisi di atas dapat dipahami bahwa gender adalah suatu sifat yang dijadikan dasar untuk mengidentifikasi perbedaan antara laki-laki dan perempuan dilihat dari segi kondisi sosial dan budaya, nilai dan perilaku, mentalitas, dan emosi, serta faktor-faktor nonbiologis lainnya. Gender berbeda dengan sex, meskipun secara etimologis artinya sama sama dengan sex, yaitu jenis kelamin. Secara umum sex digunakan untuk mengidentifikasi perbedaan laki-laki dan perempuan dari segi anatomi biologis, sedang gender lebih banyak berkonsentrasi kepada aspek sosial, budaya, dan aspek-aspek non biologis lainnya. Kalau studi sex lebih menekankan kepada perkembangan aspek biologis dan komposisi kimia dalam tubuh seorang laki-laki dan seorang perempuan, studi gender lebih menekankan kepada perkembangan aspek maskulinitas dan femininitas seseorang.

Gerakan untuk menyetarakan antara laki-laki dan perempuan ini disebut dengan feminisme. Feminisme dalam pengertian yang lebih luas adalah gerakan kaum wanita untuk menolak segala sesuatu yang dimarginalisasikan, disubordinasikan, dan direndahkan oleh kebudayaan dominan, baik dalam bidang politik, ekonomi, maupun kehidupan sosial pada umumnya. (Ratna,1999). Gerakan feminisme adalah suatu gerakan yang meminta persamaan hak wanita dan laki-laki, atau juga yang disebut dengan gerakan kesetaraan gender. Menurut The New Encyclopedia of Britanica disebutkan bahwa: "Feminism is the belief, largely originating in the West, in the social, economic, and political equality of the sexes, represented worldwide by various institutions committed to activity on behalf of women's rights and interests". (Feminisme adalah keyakinan yang berasal dari Barat berkaitan dengan kesetaraan sosial, ekonomi, dan politik antara 
laki-laki dan perempuan yang tersebar keseluruh dunia melalui organisasi yang bergerak atasnama hak-hak dan kepentingan perempuan). (Gwinn, 1988).

Dengan demikian dapat dipahami bahwa, Feminsime adalah semacam gerakan yang menuntut persamaan perlakuan dan peran antara laki-laki dan perempuan, dan tidak boleh ada diskriminasi di segala hal antara laiki-laki dan perempuan, karena lakilaki dan perempuan memiliki potensi yang sama dan kemampuan yang sama sehingga keduanya bisa menjalankan peran yang sama apabila sama-sama diberikan kesempatan untuk menjalankannya.

Fenomena tingginya angka cerai gugat ini diasumsikan oleh sebagian pihak karena adanya konsep kesetaraan gender, seperti perempuan diberikan kebebasan untuk mendapatkan pendidikan sejajar dengan laki-laki,diperbolehkan berkarir di luar rumah, mandiri secara finansial, 'melek' hukum, sehingga 'berani' menggugat cerai suaminya. Hal ini seperti yang disimpulkan oleh Isnatin Ulfah dalam penelitiannya, bahwa faktor ekonomi bukan menjadi alasan utama perempuan dalam memutuskan perceraian, tapi disebabkan oleh: pertama, keputusan gugat cerai sangat ditentukan oleh transformasi pemahaman dan kesadaran gender para pelakunya. Kedua, subyek gugat cerai memiliki pandangan yang sangat cleartentang relasi gender. Ketiga, para informan tetap memandang lembaga perkawinan sebagai lembaga yang sakral. (Isnatin Ulfah, 2011).

Fakta yang sama ditemukan oleh Muchammad Iqbal Ghozali di Pengadilan Agama Sleman, di mana perceraian di juga didominasi oleh pihak perempuan.Perbandingan cerai gugat dengan cerai talak dari sampletahun 2010 hingga 2013 meningkat melebihi 55 persen pertahunnya. Hasil dari penelitian ini menyatakan bahwa pemahaman isu kesetaraan gender menjadi salah satu pengaruh perempuan yang ada di Kabupaten Sleman mengajukan cerai gugat di Pengadilan Agama Sleman. Namun persepsi pengaruh kesetaraan gender tersebut tidak selalu bernilai negatif dikarenakan menjadi salah satu penyebab isteri mengajukan cerai gugat, karena pada hakikatnya Islam itu sendiri juga menghendaki persamaan antara laki-laki dan perempuan, keadilan bagi laki-laki dan perempuan. (Iqbal Ghozali, 2015/211).

\section{Pola Relasi Laki-laki dan Perempuan dalam Islam}

Allah Swt menciptakan manusia berpasang-pasangan antara laki-laki dan perempuan. Penciptaan ini bertujuan agar mereka saling menjalin hubungan antara 
yang satu dengan yang lain, saling mencintai, menghasilkan keturunan, hingga terciptanya perasaan kasih dan sayang di dalam berumah tangga. Allah berfirman dalam surat al-Rum ayat 21:

Artinya:

Dan di antara tanda-tanda kekuasaan-Nya ialah Dia menciptakan untukmu isteri-isteri dari jenismu sendiri, supaya kamu cenderung dan merasa tenteram kepadanya, dan dijadikan-Nya di antaramu rasa kasih dan sayang. Sesungguhnya pada yang demikian itu benar-benar terdapat tanda-tanda bagi kaum yang berfikir. (QS. Al-Rum [30]: 21).

Berdasarkan ayat di atas dapat kita pahami bahwa Allah memberi potensi yang sama dari sisi insaniyyahnya, yakni berupa potensi akal dan potensi hidup (naluri dan kebutuhan jasmani). Baik laki-laki maupun perempuan memiliki sebuah tanggungjawab terhadap keluarga, masyarakat, dan tempat di mana mereka hidup. Sebagaimana laki-laki mengambil peran aktif dan menikmati hak-hak sosialnya, perempuan juga memiliki tanggung jawab yang sama, sebagaimana dalam al-Qur'an disebutkan dalam surat al-Nisa' ayat 1 :

Artinya:

Hai sekalian manusia, bertakwalah kepada Tuban-mu yang telah menciptakanmu dari seorang diri. Dan dari padanya Allah menciptakan isterinya, dan dari pada keduanya Allah memperkembang biakkean laki-laki dan perempuan yang banyak. Dan bertakwalah kepada Allah yang dengan (mempergunakan) nama-Nya kamu saling meminta satu sama lain. Dan (peliharalab) bubungan silaturrabim. Sesunggubnya Allah selalu menjaga dan mengawasi kamu. (QS. Al-Nisa' [4]: 1).

Dari ayat di atas dapat kita pahami bahwa manusia seluruhnya berasal dari sumber yang sama. Tidak seorangpun, baik laki-laki maupun perempuan dapat mengklaim superioritas atas yang lain di alam ini. Secara rasional laki-laki tetap merupakan imam dalam keluarga. Dalam prinsip persamaan dalam konteks kemitra sejajaran perempuan dan laki-laki dapat dilihat dalam beberapa ayat al-Qur'an seperti:

Artinya:

... mereka adalah pakaian bagimu, dan kamupun adalah pakaian bagi mereka... (QS. Al-Baqarah [2]: 187).

Artinya:

....dan para wanita mempunyai hak yang seimbang dengan kewajibannya menurut cara yang ma'ruf... (QS. Al-Baqarah [2]: 228).

Ayat-ayat di atas dijadikan sebagai dasar legitimasi persamaan dan kesetaraan peran gendergender oleh kalangan feminis. Bahkan mereka menganggap bias gendergender selama ini merupakan akibat kesalahan ulama yang nota bene mayoritas laki- 
laki ketika menafsirkan ayat-ayat yang terkait dengan gendergender ini. Apalagi sosiokultural ketika buku-buku tafsir tersebut disusun budaya patriarkhi sangat mendominasi. Kalau ditelusuri lebih lanjut, maka masih banyak ayat al-Qur'an yang menjelaskan pola relasi antara laki-laki dan perempuan. Dari beberapa ayat di atas dapat dilihat dengan jelas bagaimana al-Qur'an mensejajarkan perempuan dengan laki-laki dalam berbagai aspek kehidupan. Tapi, dalam ayat lain, al-Qur'an juga memberikan pernyataan adanya keunggulan laki-laki atas perempuan, baik secara fisik maupun mental. Seperti tercantum dalam surat al-Nisa' ayat 34:

Artinya:

Kaum laki-laki itu adalah pemimpin bagi kaum wanita, oleh karena Allah telah melebibkan sebahagian mereka (laki-laki) atas sebabagian yang lain (wanita), dan karena mereka (laki-laki) telah menafkabkan sebagian dari harta mereka..... (QS. Al-Nisa' [4]: 34).

Sebagai pemimpin, laki-laki adalah penanggung jawab segala kebutuhan fisik dan kebutuhan non fisik bagi isterinya. Seorang laki-laki mempunyai hak menikahi wanita, oleh karenanya ia berhak pula untuk melepaskan apa yang dikuasainya (menjatuhkan thalak pada isterinya). Pemberian hak talak kepada suami menurut Islam adalah sesuai dengan statusnya sebagai kepala keluarga, pemimpin rumah tangga dan pemimpin wanita (Abdussalam ibn Muhammad). Dalam Islam sangat jelas disebutkan bahwa perempuan merupakan pasangan laki-laki, begitu juga laki-laki merupakan pasangan perempuan. Iman seorang perempuan dan laki-laki dinilai sama tanpa perbedaan, sama mendapat imbalan sesuai dengan pandangan dan sikap serta amal kabaikannya, memiliki hak yang sama dalam usaha memperoleh dan memiliki harta, mempunyai hak dalam memperoleh warisan, dan lain-lain. namun dalam beberapa hal terdapat perbedaan, kaum laki-laki mempunyai kelebihan hak dalam kepemimpinan, poligami, harta warisan, dan sebagainya diimbangi dengan kewajiban melindungi dan menafkahi keluarga. Perempuan memperoleh nafkah dari suaminya, namun bukan sebaliknya, tapi diimbangi pula oleh kewajiban tertentu, seperti merawat, menyusui dan membimbing anak-anaknya, dan lain-lain (Ibnu Musthafa, 1995).

Perempuan dan laki-laki, keduanya merupakan bagian dari sistem kesempurnaan penciptaan ilahi. Tanpa salah satu dari keduanya, maka penciptaanNya akan cacat. Bila umat manusia mengenal dengan baik kedudukan kedua jenis ini dalam tabiat kemanusiaan dan menggunakannya dengan baik, sistem kesempurnaan 
ilahi akan terwujud. Setiap makhluk akan mengaktualisasikan manfaat keberadaannya, sehingga tidak ada potensi yang terbuang percuma dan tidak terjadi kezaliman terhadap siapapun.

\section{METODE PENELITIAN}

Jenis penelitian yang digunakan adalah penelitian lapangan (field research) studi kasus, di Pengadilan Agama yang menjadi objek penelitian adalah PA Pekanbaru, yang dituangkan dalam bentuk kualitatif. Adapun pendekatan yang digunakan adalah pendekatan kesetaraan gender dalam Islam.Sumber data primer dalam penelitian ini adalah:(1) Wawancara (interview). Teknik pengumpulan data ini akan digunakan untuk mewawancarai beberapa pihak yang berkompeten dalam permasalahan ini, seperti yaitu paraorang hakim atau panitra di lingkungan Pengadilan Agama Kota Pekanbaru, atau dan para pelaku cerai gugat penggugat itu sendiri. Dalam menganalisis data tersebut digunakan metode deskriptif analitis,yakni menggambarkan terlebih dahulu konsep gendergender menurut para pegiat isu kesetaarn gendergender, kemudian dikomparasi dengan konsep relasi antara laki-laki dan perempuan menurut Islam. Selanjutnya gambaran tersebut dianalisis dan diinterpretasi demi tercapainya sebuah kesimpulan.

\section{HASIL DAN PEMBAHASAN}

Dalam kurun waktu 5 (lima) tahun terakhir, jumlah cerai gugat pada Pengadilan Agama Kota Pekanbaru cenderung meningkat dan lebih banyak dibandingkan cerai talak. (Wawancara dengan hakim PA Pekanbaru).Padahal secara antropologis, masyarakat kita cenderung hidup dalam sistem patriarki, di mana kekuasaan berada di tangan laki-laki dengan implikasi bahwa semua keputusan di dalam keluarga ditentukan oleh laki-laki (suami/ayah). Selain itu, pandangan masyarakat terhadap perempuan yang bercerai dianggap atau diposisikan kurang menguntungkan dan posisi ketergantungan secara ekonomi terhadap suami.Berdasarkan hasil penelitian yang dilakukan di Pengadilan Agama Kota Pekanbaru tahun 2015, diperoleh data sebagai berikut: 
Tabel 1.

Angka Cerai Talak dan Cerai Gugat di Pengadilan Agama Pekanbaru

\begin{tabular}{ccccc}
\hline No. & Bulan & Cerai Talak & Cerai Gugat & Jumlah \\
\hline 1. & Januari & 33 & 92 & 125 \\
\hline 2. & Februari & 25 & 98 & 123 \\
\hline 3. & Maret & 38 & 123 & 161 \\
\hline 4 & April & 26 & 63 & 89 \\
\hline 5 & Mei & 19 & 89 & 108 \\
\hline 6 & Juni & 28 & 89 & 117 \\
\hline 7 & Juli & 25 & 69 & 94 \\
\hline 8 & Agustus & 35 & 109 & 144 \\
\hline 9 & September & 56 & 108 & 164 \\
\hline 10 & Oktober & 45 & 109 & 154 \\
\hline & Total & $\mathbf{3 3 0}$ & $\mathbf{9 4 9}$ & $\mathbf{1 . 2 7 9}$
\end{tabular}

Secara umum, penyebab perceraian yang diputuskan oleh PA Pekanbaru ada sepuluh, dengan rincian sebagai berikut: (1) Moral (poligami tidak sehat, krisis akhlak, cemburu) (2) Meninggalkan kewajiban (kawin paksa, ekonomi, tidak ada tanggungjawab), (3) Nikah di bawah umur, (4) menyakiti jasmani (menyakiti fisik dan mental), (5) Dihukum, (6) cacat biologis/ kelainan seks, (7) Terus menerus berselisih (politik, tidak harmonis, gangguan pihak ketiga), (8) Murtad, (9) Narkoba, (10) dan lainlain. (Data dari PA Pekanbaru) Di antara penyebab yang paling dominan penyebab terjadinya perceraian di Pengadilan Agama Kota Pekanbaru adalah faktor ekonomi, dengan rincian sebagai berikut: Januari: 21 kasus, Februari: 20 kasus, Maret: 25 kasus, April: 20 kasus, Mei: 16 kasus, Juni 35 kasus, Juli: 14 kasus, Agustus: 20 kasus, September: 18 kasus, Oktober: 19 kasus. Jika dirinci lagi, unsur-unsur yang masuk ke dalam faktor ekonomi ini adalah karena tidak mampunya suami dalam memenuhi kebutuhan rumah tangga, dan pendapatan istriisteri lebih besar dibandingkan dengan pendapatan suami. Memang yang paling dominan dalam hal ini adalah karena ketidakmampuan suami dalam memenuhi kebutuhan rumah tangga. Sedangkan unsur lebih tingginya pendapatan istriisteri dibandingkan suami menjadi faktor dominan kedua. Dengan demikian, konsep pemikiran kesetaraan gendergender cukup signifikan sebagai penyebab terjadinya perceraian di Pengadilan Agama Kota Pekanbaru.

Problematika seperti contoh di atas merupakan segelintir contoh yang terjadi di kalangan masyarakat. Masalah tersebut timbul karena seorang isteri-isteri yang hidup dengan karier yang cemerlang dari padadibandingkan suaminya. Lumrahnya sebagai seorang manusia, dia tidak mau berada di bawah kekuasaan orang lain, ketika merasa bahwa dia sudah dapat hidup mandiri dan dapat memenuhi kebutuhannya sendiri. Kata 
kuncinya adalah "penghasilan" atau "pendapatan." Orang yang berpenghasilan tinggi akan lebih menampakkan kewibawaannya dibandingkan orang yang memiliki penghasilan rendah. Hal tersebut juga dapat dialami dan terjadi pada keluarga wanita karier. Bisa dibayangkan jika seorang istriisteri kariernya lebih melejit dan berpenghasilan lebih tinggi dari seorang suami. Meskipun ini masalah pekerjaan dan penghasilan, tetap tidak dapat dipungkiri ini akan berimbas pada pola kehidupan dalam keluarga. Untuk itu perlu adanya pemahaman mengenai fitrah hak dan kewajiban menurut pandangan Islam.

Pada konteks zaman sekarang memang tidak dapat menghindari keterlibatan seorang wanita dalam pencaturan dunia sosial dan karier. Tapi, harus dipahami bahwa keikutsertaan seorang istriisteri dalam mencari penghasilan, tidak menjadikan mereka tidak melaksanakan kewajibannya sebagai seorang istriisteri. IstriIsteri tetap wajib melaksanakan tugasnya melayani suami dan mengatur kehidupan rumah tangganya. Apabila ketika masih terjadi silang sengketa masalah perbedaan pendapatan dan penghasilan antara keduanya, perlu diadakan pemahaman bahwa suami tetap menjadi pemimpin keluarga dan yang paling berkewajiban mencari nafkah. Jika suami mengalami kesulitan, maka hendaknya istriisteri tidak berpaling dari suaminya, dan tidak memutuskan untuk berpisah dengan suaminya.

Apabila seorang suami tidak mampu mencukupi kebutuhan rumah tangganya karena miskin, istriisteri boleh membantu dengan bekerja. Hal tersebut harus dianggap sebagai salah satu bentuk tolong-menolong. Perbedaan pendapatan jangan dijadikan alasan untuk berpisah, karena ikatan yang terjalin dari akad pernikahan akan membawa dampak kehidupan yang harus dirajut berdua dengan saling tenggang rasa, namun tidak mengurangi pemahaman bahwa nafkah keluarga masih merupakan kewajiban seorang suami. Meskipun seorang istriisteri memiliki kesibukan lain di luar rumah, hendaklah tidak meninggalkan tanggung jawab sebagai seorang istriisteri yakni melayani suami dan mengurus keperluan rumah tangganya dengan baik, karena tugas utama seorang wanita menurut Islam memang berada di dalam rumah dan mengatur kehidupan rumah tangga.

\section{E. SIMPULAN}

Dari uraian di atas dapat disimpulkan bahwa paradigma kesetaraan gender termasuk faktor penyumbang tingginya cerai gugat di PA Pekanbaru, walaupun bukan sebagai faktor utama.Kesetaraan gender di sini bisa bermakna positif dan negatif. Bermakna positif apabila dikaitkan dengan kesadaran hukum bagi perempuan sebagai 
solusi atas kekisruhan rumah tangga yang dialaminya, di mana kesadaran itu diperolehnya melalui akses kesempatan pendidikan yang sama dengan kaum laki-laki, sehingga meningkatnya kesadaran perempuan akan hak-haknya.Sebaliknya, kesetaraan gender berkonotasi negatif apabila kelebihan yang dimiliki oleh perempuan tersebut dijadikan alasan untuk "membuang" laki-laki (suami) dengan cara menggugat cerainya di Pengadilan Agama.

Walaupun para informan tidak terlalu paham terhadap konsepsi tentang gender, namun secara umum pandangan para informan memiliki kesesuaian konseptual dengan pandangan feminisme liberal, di mana perempuan harus mempunyai hak yang sama dengan laki-laki. 


\section{DAFTAR REFERENSI}

Abdussalam ibn Muhammad dengan judul "Atsar al-Mar'ah fi Nafaqah al-Zanjizyah" yang disampaikan pada khalaqah yang dilaksanakan oleh Pusat Kajian Fiqih Kontemporer Universitas Imam ibn Su'ud.

Al-Asqalani, Ibnu Hajar, Fath al-Bari, Dar al-Fikr, Beirut, 1989.

Al-Jaziri dalam Al-Fiqh ala Al-Madzahib Al-Arba'ah.

Al-Syirazi, Abu Ishaq Ibrahim al-Fairuzzabadi, al-Muhadzdzab, Dar al-Fikr, Beirut, 1987.

Giddens, Anthony, Sociology, Cambridge University Press, Cambridge, 1997.

Gwinn, Robert. P, The New Encyclopedia Britanica, Chicago University Press, Chicago, 1988.

Ibnu Musthafa, Wanita Menjelang Tabun 2000, al-Bayan, Bandung, 1995.

Isnatin Ulfah, "Menggugat Perkawinan: Transformasi Kesadaran Gender Perempuan dan Implikasinya terhadap Tingginya Gugat Cerai di Ponorogo," Jurnal Kodifikasia, Vol. 5 No. 1 Tahun 2011.

Macionis, John. J, Sociology, Pearson Education, Tonton, 2006.

Megawangi, Ratna, Membiarkan Berbeda?; Sudut Pandang Baru tentang Relasi Gender, Mizan, Bandung 1999.

Muzhar, Atho' (ed), Wanita dalam Masyarakat Indonesia, Sunan Kalijaga Press, Yogyakarta, 2001. 